ISSN 2078-6441. Вісник Львівського університету. Серія географічна. 2013. Випуск 41. С. 282-294. Visnyk of the Lviv University. Series Geography. 2013. Issue 41. P. 282-294.

$55: 502.64$

,

нн іренко

ьвівський н ціон льний університет імені в н

вул. . орошенк, 41, 79000, м. ввів, кр їн

пис но ст н і специфіку природно-з повідного фонду ольщі, зокрем в тій ч стині, як стосується охорони об'єктів неживої природи. истем тизов но досвід н ших сусідів пристосув нням н явних природоохоронних к тегорій до нових, які ктивно ввійшли в н ше життя протягом ост ннього десятиліття, н ведено н йцік віші кл сифік ції і принципи, що взяті $з$ основу їхнього створення.

лючові слов : форми охорони природи, геоохорон, георізном ніття, геологічн сп дщин , геомісце, геоп рк, геотуризм.

ля ольщі, незв ж ючи н невелику площу, х р ктерне 6 г тство геологічної будови, форм рельєфу, флори і ф уни. р диції охорони природної сп дщини сяг ють у цій кр їні ч сів перших королів - олесл в ороброго, який ще в ст. увів з борону полюв ти н бобрів, т зимир еликого, який першим н к з в охороняти ліси. дн к, м буть, б г тство природного середовищ і глибокі тр диції - не єдин причин позитивної ситу ції зі ст ном природоохоронної спр ви у ольщі. кр їн м є не менше біо- і георізном ніття й тр диції з повідної спр ви, проте сьогодні ч стк 3 повідності кр їни ст новить лише 5,4\% [1], тоді як у ольщі - 32,4\% території кр їни, і це без ур хув ння мережі територій "Natura 2000” [2].кр їні ст ном н 1 січня 2010 р. н лічув в 7606 територій [1], в ольщі тоді ж було у 6 р зів більше - 45636 об'єктів [2]. ч стки з повідності європейських кр їн н рівні $12-15 \%$ ольщу нині впевнено можн з числяти до кр їн-лідерів у г лузі охорони довкілля, досвід яких можн і потрібно вивч ти.

ш мет - $\mathrm{x}$ р ктеристик теперішнього ст ну ольщі, особливо в тій його ч стині, як стосується об'єктів неживої природи, н ліз специфіки структури дещо відмінної від укр їнської, н ліз б г того досвіду н ших сусідів у створенні об'єктів , проблем, що виник ють з пристосув нням природоохоронних к тегорій до нових вимог і нових тенденцій у розвитку природоохоронної спр ви у зв'язку з входженням у вропейську структуру, опис н йцік віших кл сифік цій об'єктів принципів їхнього виділення і використ ння нтернету для поширення інформ ції про цік ві об'єкти неживої природи.

хорону природи в ольщі регулюють положення $\quad$ кону про охорону природи від 16 квітня 2004 р. [14]. гідно 3 цим 3 коном, охорон природи поляг є в збереженні, зрівнов женому користув нні т відновленні з п сів, утворень і скл дників природи.

ст. 6 цього з кону визн чено десять основних к тегорій - форм охорони природи:

1) н ціон льні п рки,

2) природні з повідники,

3) л ндш фтні п рки,

(C) іренко ., 2013 
4) охоронні л ндш фти,

5) простори "Natura 2000",

6) п м'ятки природи,

7) документ льні місця,

8) екологічні угіддя,

9) природно-л ндш фтні комплекси,

10) охорон видів рослин, тв рин і грибів.

лощ всього природно-з повідного фонду ольщі (без територій Natura 2000) н прикінці 2010 р. ст новил пон д 10,1 млн г, тобто 32,4\% території кр їни [2]. орми неживої природи охороняють як безпосередньо, т к і опосередков но в усіх перелічених к тегоріях, з винятком ост нньої, у меж х територі льних т в об'єктних форм х природно-з повідного фонду. о форм природно-з повідного фонду н леж ть п м'ятки неживої природи і документ льні місця.

озглянемо дешо дет льніше скл дові польського природно-з повідного фонду.

ціон льні п рки (пол. parki narodowe, нгл. national parks) - головн скл дов системи охорони, з йм є н йвищу позицію серед форм охорони природи в ольщі.

ольщі нині є 23 н ціон льні п рки з г льною площею 314,5 тис. г , тобто 1 \% площі кр іни (т бл. 1). ціон льний п рк охоплює територію, що вирізняється особливими природними, н уковими, культурними й освітніми цінностями, площею не менше 1000 г , у меж х якої охороні підляг є вся природн систем т її л ндш фтні цінності.

блиця 1

тегорії охорони природи в ольщі [2]

\begin{tabular}{|c|c|c|}
\hline риродоохоронні об'єкти & ількість & лощ , Г \\
\hline ціон льні п рки & 23 & 314474,5 \\
\hline риродні з повідники & 1463 & 164202,1 \\
\hline ндш фтні п рки & 121 & 2529022,0 \\
\hline хоронні л ндш фти & 386 & 6990047,7 \\
\hline ериторії Natura 2000 & $\begin{array}{l}967 \text { (144 - території } \\
\text { спеці льної охорони } \\
\text { пт хів + } 823 \text { - спеці льні } \\
\text { території охорони } \\
\text { біотопів) }\end{array}$ & 9362632,0 \\
\hline кологічні угіддя & 6877 & 51029,5 \\
\hline риродні-л ндш фтні комплекси & 318 & 93463,6 \\
\hline окумент льні місця & 155 & 885,2 \\
\hline м’ятки природи & 36293 & - \\
\hline весь природно-з повідний фонд & 45636 & $\begin{array}{l}10143124,6 \text { ( без } \\
\text { територій рирод 2000) }\end{array}$ \\
\hline
\end{tabular}

ольщ прийнял визн чення н ціон льного п рку, з тверджене н Х (1969) i XI (1972) з’їз х іжн родної спілки охорони природи і природних ресурсів (IUCN-WCU). сі польські н ціон льні п рки, які відповід ють вимог м IUCN, опинилися в іï списку, зокрем 15 отрим ло другу к тегорію, 2 п рки отрим ли п'яту к тегорію ( йцовський і ігерський). ість п рків ( єбж нський, ори Тухольські, толових ip, рвянський, гурський, итоки рти) тоді ще не було, тому вони не прокл сифіков ні IUCN-WCU. крім того, дев'ять н ціон льних п рків UNESCO внесл у список біосферних з повідників ( бьогурський, іловезький, ещ дський, ори ухольські, мпіноський, рконоський, оліський, ловінський, трш нсь- 
кий), зокрем один ( іловезький) був визн ний UNESCO об'єктом світової сп дщини [11]. ериторія п рків доступн для відвідув ння, одн к туристичний рух може відбув тися винятково визн ченими стежк ми. меж х п рків н площі 68 тис. г (21\% площі всіх н ціон льних п рків) виокремлено зони т к зв ної стислої охорони (з повідні), де вз г лі з боронене будь-яке втруч ння людини в екосистему. йменший у ольщі йцовський п рк - 2146 г , н йбільший - єбж нський - 59223 г . ціон льні п рки в ольщі м ють лісовий х р ктер, пр ктично $62 \%$ їхньої площі 3 йм ють ліси. иняток - “ итоки рти”, у якому ліси ст новлять лише $1 \%$ площі, i “ рвянський” (площ лісів - $3 \%$ ), у якому основною цінністю є унік льний х р ктер p. рев ( н стомозув льне русло).

риродні з повідники (пол. rezerwaty przyrody, нгл. nature reserves) - цінні природні просторові форми охорони природи, менші 3 площею. прикінці 2010 р. кількість об'єктів цього типу досягл 1463, їхня з г льн площ ст новил пон д 164 тис. г , (0,5\% площі кр їни і 1,6\% площі природоохоронного фонду кр іни) (див. т бл. 1). кон від 16 квітня 2004 р. визн ч є природний $з$ повідник як територію, як охоплює простори, збережені в незміненому бо м лозміненому ст ні, екосистеми, біотопи рослин, тв рин, грибів т об'єкти і скл дники неживої природи, що м ють особливі природні, н укові, культурні бо л ндш фтні цінності [14]. редметом охорони в з повіднику може бути вся природн систем бо окремі іiі скл дники, зокрем , ф ун , флор , біот грибів, об'єкти неживої природи. ся територія з повідник бо його ч стини може підляг ти обмеженій охороні, ктивній охороні бо л ндш фтній охороні. повідники поділяють н дев'ять типів 3 кл сифік цією . убінського [4]: лісовий, флористичний, торф'яний, ф уністичний, л ндш фтний, неживої природи, водний, степовий, г лофітний. Серед природних з повідників лише 73 (5\%), з г льною площею 2132 г н леж ть до к тегорії з повідників неживої природи (див. т бл. 1). рикл дом може бути з повідник неживої природи “ ор борів” (45 г ) в меж х р ківсько- енстоховської височини з в пняковими ост нцями висотою до 30 м, к рстовими лійк ми, к рстовими печер ми, у які відкрито доступ туристів, бо з повідник неживої природи “ осьцьож” (174 г) у уявськооморському воєводстві, розт шов ний н тер сі орунсько- берсв льдської пр долини, головною метою охорони в якому є збереження унік льних серій ш рув тих донних озерних відкл дів віком пон д 12 тис. років.

ндш фтні п рки (пол. parki krajobrazowe, нгл. landscape parks). ншим в жливим скл дником природно-з повідного фонду ольщі $є 121$ л ндш фтний п рк з г льною площею пон д 2,5 млн г, що ст новить пон д $8 \%$ площі кр їни (див. т бл. 1). собливістю л ндш фтних п рків, н відміну від попередніх форм природно-з повідного фонду, є те, що в них можн вести господ рську діяльність. ндш фтний п рк створюють н території, що м є природні, історичні і культурні т л ндш фтні цінності для збереження, популяриз ції цих цінностей в умов х зрівнов женого розвитку. кий п рк повинен слугув ти кр єзн вчій рекре ції, тобто туризму, відпочинку, т кож освіті [8]. оч в меж х л ндш фтних п рків і допустим нтропогенн діяльність, проте є певний перелік з борон, які можуть з стосовув ти в п рку. ерелік цих з борон визн ч є ст. 17 кону про охорону природи [14]. е зн чно менш рестриктивн форм охорони природи порівняно з н ціон льними п рк ми і природними з повідник ми, одн к не менш популярн . прикл д, у юблінському, прикордонному з кр їною, воєводстві лок лізов но 17 т ких п рків. йст рший л ндш фт- 
ний п рк у ольщі - “ ув льський” (1976), н йбільший з площею - л ндш фтний п рк “ олин ричі” (пон д 84 г ).

хоронні л ндш фти (пол. obszary chronionego krajobrazu, нгл. protected landscape areas). кі території з йм ють зн чні площі - річкові долини, лісові комплекси, горбогір'я, дюнні поля, торфовищ тощо. і простори вв ж ють цінними 3 огляду н винятковий л ндш фт, б г тство екосистем бо виконув ну ними функцію екологічних коридорів між в жливішими простор ми, які охороняють, н прикл д н ціон льними, л ндш фтними п рк ми і з повідник ми. і території цінні, оскільки д ють змогу з довольняти потреби, пов'яз ні з туризмом і відпочинком [10]. д ними н кінець 2010 р., у ольщі існув ло 386 територій л ндш фту, що перебув ли під охороною, 3 г льною площею м йже 7 млн г, бо $22,3 \%$ від площі кр їни (див. т бл. 1). е одн 3 н йменш рестриктивних просторових форм охорони природи в ольщі з м ло обмежув льним охоронним режимом. оловне призн чення територій л ндш фтів, які перебув ють під охороною, - рекре ція, господ рськ діяльність підляг є лише незн чним обмеженням (з борон будівництв об'єктів, шкідливих для середовищ, і нищення н вколишнього середовищ ). рикл дом охоронних л ндш фтів можуть бути “ буєнські друмліни”, 7085 г (уявськооморське воєводство); “ олин угу”, 30162 г ( ідляське воєводство); “ зи єльовицькі”, 815 г ( идгоське воєводство); “" рдські і овині гори”, 22500 г ( ольношльонське воєводство).

ереж територій “Natura 2000” (пол. siec obszarów Natura 2000, нгл. Natura 2000 network of protected areas) - це комплексн європейськ екологічн мереж, яку створюють у вропі для збереження природних біотопів i видів, яким з грожує зникнення. ольщі цю форму охорони впров джено 2004 р. л нують, що т кі простори охоплять близько 15-20\% площі кр їни. ридичною підст вою створення мережі “Natura 2000” є дв юридичні кти: иректив ди 79/409/EWG від 2 квітня 1979 р. у спр ві охорони дикого пт ств (т к зв н т шин директив ), т иректив

ди 92/43/EWG від 21 тр вня 1992 р. у спр ві охорони природних біотопів і дикої ф уни т флори (т к зв н іотопн директив ). они передб чують створення системи просторів, з'єдн них екологічними коридор ми, тобто фр гмент ми л ндш фту, які уможливлюють мігр цію, поширення й обмін генетичного фонду видів. вд нням мережі є збереження біорізном ніття з вдяки охороні не лише н йцінніших і н йрідкісніших елементів природи, т кож н йбільш типових, н йбільше поширених природних систем, х р ктерних для біогеогр фічних регіонів (н прикл д, льпійського, тл нтичного, континент льного). ериторія "Natura 2000" може охоплюв ти ч стину бо сукупність просторів і об'єктів, де 3 діяні інші форми охорони природи. осі в ольщі були визн чені 144 простори спеці льної охорони пт хів (Special Protection Areas - SPA) т 823 простори, що м ють зн чення для (Special Areas of Conservation - SAC) (див. т бл. 1).

м'ятки природи (пол. pomniki przyrody, нгл. natural monuments). кон про охорону природи від 2004 р. визн ч є п м'ятки природи як окремі об'єкти живої і неживої природи бо їх скупчення, які м ють особливу природну, н укову, культурну, історичну бо пейз жну цінність т індивіду льні озн ки, які вирізняють їх серед інших об'єктів [14]. д ними ст ном н 31 грудня 2010 р. кількість п м'яток природи в ольщі ст новил 36293 (див. т бл. 1). еред п м'яток природи окрему групу ст новлять п м'ятки живої природи (дерев, групи дерев, леї - 33717 ) і зн чно меншу - тільки трохи більше 5 \% усіх п м'яток природи - п м'ятки неживої природи, 
серед яких н йбільше ер тичних в лунів - 1 034, решт (604 об'єкти) - цік ві форми рельєфу, т кі як джерел , водосп ди, яри, скелі, фр гменти вріз них долин, печери, к р'єри тощо. о н йцік віших п м'яток неживої природи н леж ть скелі “ ортовий к мінь” у гурському н ціон льному п рку, “ул в еркулес ” в йцовському н ціон льному п рку, пульсуюче джерело “ жорд н” у цібожиц х, водосп д $\mathrm{i}$ мінер льні джерел “ омніч нкі” в омніци- дрою, “ т в єшхомля” в єшхомлі єлькей, “ оронячі келі” в жм ніц х- дрою, “ іпсові крист ли” в уску- дрою, н йбільший ер тичний в лун у ольщі “ ригл в” (50 м у периметрі) в хіднопоморському воєводстві, ер тичний в лун “ д м” у рку еромського в еціні, “р тичні в луни номів” у ожешові, к рстов печер “елосьов м” в вожно і б г то інших.

окумент льні місця (пол. stanowiska dokumentacyjne, нгл. documentation sities) це індивіду льн форм охорони неживої природи, як передб ч є охорону місць, цінних 3 н укового і дид ктичного погляду. кими місцями можуть бути специфічні форм ції т геологічні профілі, відслонення, товщі порід, які містять ск м'янілі рештки орг нізмів, місця, з яких походять нововідкриті види викопної ф уни бо флори, печери, фр гменти експлу тов них бо недіючих поверхневих і підземних виробок.

сто ними є місця, які зовсім не виділяються н поверхні землі, одн к про їхню н явність свідчить відповідн інформ ційн т блиця. окумент льне місце з тверджують ухв лою р ди гміни, тобто місцевих орг нів с моврядув ння. ет льн сфер обмежень і з борон для конкретного документ льного місця визн чен в розпорядженні бо ухв лі, як з тверджує його створення. борони, які можн з стосув ти в меж х документ льного місця, перер хов ні в ст. 45 п. 1. кону про охорону природи, вони т кі ж, як і у вип дку п м'яток природи [14]. д ними ст ном н 31 грудня 2010 р. кількість документ льних місць у ольщі ст новил 155 (з г льн площ - 885,2 г ) (див. т бл. 1). л сифік ція документ льних місць неживої природи 3 генезисом охоплює: ) місця, сформов ні вн слідок домінув ння ерозійних процесів - відслонення і профілі відкл дів у річкових долин х (річков ерозія) бо н кліфових узбережжях т деякі форми рельєфу, т кі як яри (річков ерозія, площинний змив), печери в піщ них ос дових відкл д х (ерозія підземних вод), льодовиков поліровк, ер тичні в луни (льодовиков ерозія); б) місця, сформов ні вн слідок домінув ння денуд ційних процесів - відслонення в меж х вершинних п ртій височин і підвищень (звітрюв ння), денуд ційні ост нці (звітрюв ння у в пнякових пород х, розчинення); в) місця, сформов ні вн слідок домінув ння кумулятивних процесів - форми рельєфу, сформов ні в четвертинний ч с: морени (льодовиков кумуляція), дюни (еолов кумуляція); г) місця, сформов ні вн слідок домінув ння к рстових процесів - форми рельєфу, пов'яз ні 3 к рстовою ерозією в пнякових порід (печери, к рстові лійки), к рстові джерел ; д) місця, сформов ні вн слідок домінув ння зсувних процесів - предст влені зсувними форм ми рельєфу в піщ них і супіщ них відкл д х т відслоненнями, які виникли вн слідок зсувних процесів; е) місця, які є н слідком діяльності людини перев жно відслонення і профілі різних відкл дів у діючих бо недіючих к р'єр х, недіючі к меноломні (зі збереженими профілями стінок), ш хти; є) місця, сформов ні вн слідок різних процесів (полігенетичні) - місця, у яких не можн однозн чно визн чити перев ж ючий геоморфологічний процес. л сифік ція документ льних місць неживої природи з ур хув нням їхньої цінності охоплює місця, які м ють: ) н уково-дид ктичну цінність, предст влені відслоненнями і профілями; б) п леонтолого-стр тигр фічну цінність; в) стр тигр фічно-літологічну цінність; 
г) седимент ційну бо тектонічну цінність; д) п леогеогр фічну цінність; е) з г льнон укову цінність; є) туристично-кр єзн вчу цінність, предст влені форм ми рельєфу бо груп ми форм: денуд ційні й денуд ційно-к рстові ост нці, печери; к рстові лійки і пров лля; зсуви; яри; морени; дюни; поексплу т ційні виробки і к меноломні; водосп ди; джерел . рикл дом т ких місць у ольщі є: документ льне місце " рі с" - п леонтологічн зн хідк н території глиняного к р'єру в р сєйові ( польське воєводство) з добре збереженими рештк ми мезозойських метопоз врів і фітоз врів т інших груп орг нізмів, т ких як молюски, дводих льні риби, г ноїди, х рові водорості. нший прикл д - документ льне місце “ялохово” у уявськооморському воєводстві - н площі в 93,52 г охороняється унік льний фр гмент моренної височини; документ льне місце “ ечер ертиця”-н території р ківськоенстоховської височини ( ілезьке воєводство) з системою к рстових коридорів і кімн т довжиною 210 м і різницею рівнів 31 м.

кологічні угіддя (пол. и ytki ekologiczne, нгл. ecological arable lands) - фр гменти екосистем, які з слуговують н охорону і м ють зн чення для збереження біорізном ніття - н тур льні водойми, лісові й кущові н с дження, болот, торфовищ , дюни, ст риці, скельні відслонення, природні відкоси, місця лок ліз ції рідкісних бо т ких, що перебув ють під охороною, видів рослин, тв рин, грибів тощо. кологічні угіддя н леж ть до об'єктних, тобто індивіду льних форм охорони природи. уттєвою причиною створення екологічних угідь $є$ потреб охорони невеликих 3 площею, проте цінних з природного погляду природних об'єктів. они не можуть бути охоплені охороною як просторові об'єкти з огляду н невелику площу і з звич й нижчий р нг природних цінностей. ольщі виділено 6877 екологічних угідь з г льною площею пон д 51 тис. г (див. т бл. 1). думку н літиків, екологічні угіддя - дієве зн ряддя охорони н вколишнього середовищ, яке використовують у ольщі не повною мірою. рикл дом екологічних угідь, у яких охороняють геоморфологічну скл дову, може бути “ лендовськ пустеля” (683,91 г ). етою охорони цього простору є збереження 3 н укових, дид ктичних і л ндш фтних міркув нь 3 лишків н йбільшого в ольщі простору континент льних дюнних пісків 3 цік вими морфологічними форм ми, численними рідкісними вид ми флори, ф уни, які перебув ють під охороною. “ лендовську пустелю” вв ж ють великою природною особливістю не лише в м сшт бі ольщі.

риродно-л ндш фтні комплекси (пол. zespoty przyrodniczo-krajobrazowe, нгл. landscape nature complexes) - фр гменти н тур льного і культурного л ндш фту, який з слуговує н охорону з огляду н естетичні й пейз жні цінності. інну з природного погляду територію цією формою охорони охоплюють іноді тимч сово як територію, як в м йбутньому може ст ти природним з повідником. д ними ст ном н 31 грудня 2010 р. кількість природно-л ндш фтних комплексів у ольщі ст новил 318 3 г льною площею пон д 93 тис. г (див. т бл. 1). оловно це фр гменти долин рік, зокрем їхні витоки, озер, торфовищ, горобогір'я, комплекси ст вів тощо. рикл ди природно-л ндш фтних комплексів, у яких естетичну цінність ст новить, зокрем , рельєф: комплекс “ пнякові ори” у меж х л ндш фтного п рку “ ежріччя рти і ід вки" площею 3,64 г - він охоплює фр гмент долини р. рт, де відслонені верхньоюрські в пняки і мергелі; “ рочище юбневське”, створене для збереження в н тур льному ст ні озер юбневсько т його м льовничих прибережних круч; “ олин p бi” в одзькому воєводстві (478 г ) - створен для збереження м льовничої вузької глибоко вріз ної м ндрівної долини; “им вський оз” (площ 1,37 г ) у 
орунському воєводстві, створений для охорони міш них лісів, що сформув лися н водно-льодовиковій формі рельєфу.

кщо ще зовсім нед вно геоморфологи і геологи зосереджув ли зусилля н виділенні п м'яток неживої природи т документ льних місць, їхній охороні в меж х великопросторових природоохоронних об'єктів (н ціон льних, л ндш фтних п рків, з повідників) т 3 їхніми меж ми, то ост нніми рок ми мод н геотуризм, як прийшл 3 ходу, дещо скоригув л їхню діяльність. ісля входження в ольщ сумлінно з пров джув л всі нововведення, пропонов ні дміністр цією, зокрем і в природоохоронній сфері. ині тр диційне визн чення “охорон неживої природи” (пол. ochrona przyrody nieo ywionej, нгл. inanimate nature protection) поступово витісняє термін геоохорон (пол. geoochrona, нгл. geoconservation), як поляг є у збереженні георізном ніття (пол. georó norodnośc, н нгл. geodiversity) геологічної сп дщини (пол. dziedzictwo geologiczne, нгл. geoheritage), iї основних бо в жливих екологічних озн к т усп дков них цінностей. 'явил ся низк нових термінів: геомісце (пол. geostanowisko, нгл. geosites, нім. geotope), геоп рк (пол. geopark, нгл. geopark), геотуризм (пол. geoturystyka, нгл. geotourism) і необхідність їх пристосув ння до вже н явних природоохоронних к тегорій і уніфік ції в єдиній системі форм охорони природи, можливо, н віть і створення нових природоохоронних к тегорій.

еомісц, бо геос йти, бо геотопи, якщо з стосовув ти к льку з польської, нглійської чи німецької (пол. geostanowisko, нгл. geosites, нім. geotope), - це елементи неживої природи, які м ють вир зну інформ цію про розвиток земної кори бо життя н емлі, яким вл стиві цінні з туристичного і пізн в льного поглядів геологічні бо геоморфологічні особливості, які з документов ні під ч с інвент риз ції й оцінюв ння. ояв кільк років тому нового термін зумовил потребу його пристосув ння до p ніше виділених у ольщі форм охорони природи (див. т бл. 2). це виявилося спр вою непростою. дже в польській пр ктиці цей термін охоплює і п м'ятки неживої природи (скелі, ер тики, печери, джерел , водосп ди), і документ льні місця (відслонення, печери), і екологічні угіддя, і деякі природно-л ндш фтні комплекси, особливо цінні з погляду геоохорони. ротягом ост ннього десятиліття в ольщі створено кільк різних 6 з д них геомісць, зокрем, ольський 6 нк д них GEOSITES i ентр льний реєстр геомісць ольщі, які охоплюють як цінні об'єкти неживої природи офіційних к тегорій , т к і об'єкти, які в жодну з цих к тегорій не внесені, проте н дзвич йно цінні з геологічного і геоморфологічного поглядів.

ольський б нк д них GEOSITES. ольський $б$ нк д них GEOSITES, який н лічує 175 об'єктів, викон ний під керівництвом проф. офії лекс ндрович в нституті охорони природи ольської к демії н ук у р кові. ого скорочен версія опубліков н в "Nature Conservation" (Vol. 62 (5), 2006), нтернет-версія доступн н сервері інституту [6]. ошук можн виконув ти з різними ключ ми: віком порід (н прикл д, трі с), віком процесів (к рбон), воєводством ( юблінське), фізико-геогр фічним поділом ( олинське олісся), х р ктером порід (ск жімо, леси), формою охорони (л ндш фтний п рк), дисципліною, що вивч є (геоморфологія). езульт т пошуку предст влений н екр ні дет льною інформ цією, як охоплює місцезн ходження, фр гмент к рти, дет льний опис, список літер тури про цей об'єКт тощо.

ентр льний реєстр геомісць ольщі (пол. Centralny Rejestr Geostanowisk Polski). 2010 р., нез лежно від 6 зи С. лекс ндрович, н з мовлення міністр середовищ , ерж вний геологічний інститут створив ентр льний реєстр геомісць ольщі, у якому зібр но інформ цію про н йцінніші об’єкти неживої природи в ольщі - окремі відсло- 
нення, групи відслонень, скельні утворення, ер тичні в луни, к рстові форми, форми звітрюв ння т ін. [3]. ентр льному реєстрі геомісць ольщі пошук можн виконув ти $з$ : 1) лок ліз цією згідно з: ) дміністр тивним поділом, б) номером ркуш к рти, в) геологічним р йонув нням; 2) типом об'єкт : ) природне геологічне відслонення, б) штучне геологічне відслонення, в) кумулятивн форм рельєфу, г) денуд ційн форм рельєфу, д) водний об'єкт, е) гірничодобувний об'єКт, є) п леонтологічн стоянк , ж) місцезн ходження цік вих мінер лів бо скель; 3) р нгом об'єкт : ) $з$ г льнодерж вний, б) лок льний, в) міжн родний, г) регіон льний; 4) розт шув нням:

) н туристичному шляху, б) н території п рку, в) непод лік від туристичного шляху, г) н відлюдді; 5) доступністю: ) утруднений доступ, б) легкодоступний, в) недоступний, г) в жкодоступний, д) потребує спеці льного обл дн ння.

блиця 2

еомісця ольщі з поділом з р нг ми об’єктів (ст ном н 31.07.2012) [3]

\begin{tabular}{|c|c|c|c|c|c|c|}
\hline \multirow[b]{2}{*}{ оєводство } & \multicolumn{4}{|c|}{ нги об’єктів } & \multirow[b]{2}{*}{ ількість } & \multirow{2}{*}{$\begin{array}{c}\text { ількість, } \\
\%\end{array}$} \\
\hline & міжн родний & $\begin{array}{c}3 \text { г льно- } \\
\text { держ вний }\end{array}$ & $\begin{array}{c}\text { регіон ль- } \\
\text { ний }\end{array}$ & $\begin{array}{c}\text { лок ль- } \\
\text { ний }\end{array}$ & & \\
\hline ольношльонське & 0 & 7 & 93 & 47 & 147 & 7,8 \\
\hline уявсько-поморське & 0 & 12 & 16 & 13 & 41 & 2,2 \\
\hline юблінське & 20 & 36 & 141 & 105 & 302 & 16,0 \\
\hline юбуське & 2 & 2 & 12 & 9 & 25 & 1,3 \\
\hline одзьке & 0 & 11 & 40 & 16 & 67 & 3,6 \\
\hline лопольське & 12 & 33 & 191 & 46 & 282 & 14,9 \\
\hline зовецьке & 1 & 16 & 18 & 38 & 73 & 3,9 \\
\hline польське & 4 & 2 & 27 & 17 & 50 & 2,6 \\
\hline ідк рп тське & 3 & 9 & 81 & 39 & 132 & 7,0 \\
\hline ідляське & 4 & 11 & 21 & 34 & 70 & 3,7 \\
\hline оморське & 0 & 12 & 88 & 29 & 129 & 6,8 \\
\hline льонське & 6 & 18 & 75 & 47 & 146 & 7,7 \\
\hline вєнтокшиське & 18 & 27 & 98 & 30 & 173 & 9,2 \\
\hline рмінсько- зурське & 3 & 20 & 12 & 19 & 54 & 2,9 \\
\hline еликопольське & 1 & 17 & 41 & 6 & 65 & 3,9 \\
\hline хіднопоморське & 13 & 35 & 60 & 24 & 132 & 7,0 \\
\hline 30M & 87 & 268 & 1014 & 519 & 1888 & 100 \\
\hline
\end{tabular}

езульт т пошуку предст влений н екр ні у восьми з кл дк х: 1) з г льн х р ктеристик , як охоплює б зову інформ цію про об’єкт, зокрем , конкретне місцезн ходження (координ ти GPS), можливість доїзду, форму вл сності території; 2) фізичні п р метри: довжин , ширин , висот, площ, висот н д рівнем моря; 3) кту льний ст н: форм вл сності, ст тус, ст н збереження, розт шув ння, доступність, р нг об'єкт , оцінк дид ктичної, туристичної, н укової прив бливості в б л х, з г льн оцінк прив бливості об'єкт ; 4) геологічн х р ктеристик : геологічне р йонув ння, вік, літологія, форм рельєфу, генезис, дет льн геологічн х р ктеристик об'єкт ; 5) гр фічн документ ція: фото, д т викон ння, втор; 6) опр цюв ння; 7) бібліогр фія; 8) к рт . к дет льно опис но кожне геомісце, т ких сьогодні (31.07.2012) - 1888 одиниць!

еоп рки (пол. geoparki, нгл. geoparks). 2004 p. IUGS вирішив створити нову одиницю для промоції геологічної сп дщини і поч в підтримув ти ініці тиви орг ніз ції вропейської мережі геоп рків ( нгл. European Geoparks Network $(E G N)$ і лоб ль- 
ної ережі еоп рків ( нгл. Global Geoparks Network (GGN), яку п тронує

епер геоп рки - н йв жливіш міжн родн к тегорія охорони геологічної сп дщини. еоп рк - це територія з визн ченими меж ми, цік вою геолого-геоморфологічною історією, у якій є поодинокі бо моз їчно розміщені об'єкти, цік ві з геологічного, геоморфологічного, п леонтологічного поглядів (геомісця), в жливі з погляду н уки, рідкісності бо типовості поширення, естетичної, н вч льної бо туристичної цінності, 3 документов ні в ході інвент риз ції й оцінюв ння. еоп рки не є юридичною формою охорони неживої природи, як об'єкти природно-з повідного фонду, визн чені коном про охорону природи від 16 квітня 2004 р. і можуть м ти різний р нг, почин ючи від місцевого зн чення, з г льнодерж вного до європейського і світового.

ольщі, як і в інших кр їн х, н йбільш відповідними простор ми для т кої форми охорони є л ндш фтні п рки, які охоплюють зн чні території, що м ють в жливе зн чення для н ук про емлю, одноч сно доступніші, ніж інші території, що перебув ють під охороною, для туристичного і дид ктичного використ ння. еоп рки можн створюв ти і в інших місцях. ісцевий геоп рк - це геоп рк н йнижчого р нгу. ого можн створити вн слідок домовленості (і відповідної ухв ли) місцевих суб'єктів (орг нів місцевої вл ди, орг нів охорони природи, предст вників н уки), сконцентров них довкол ідеї промоції геологічної сп дщини, в умов х зрівнов женого розвитку. ісцеві геоп рки не є член ми мережі європейських і світових геоп рків, проте існує можливість їх верифік ції вн слідок н д ння їм відповідного ст тусу н ціон льного (з г льнодерж вного) геоп рку. ініці тиви головного геолог ольщі енрик цк зерського груп експертів розпоч л роботу, спрямов ну н вироблення принципів і процедур н $б$ зі місцевого виділення геоп рків з г льнодерж вного зн чення в ольщі.

ершим об'єктом у ольщі, який 21.10.2009 р. отрим в сертифік т геоп рку з г льнодерж вного зн чення, бул “" уг уж ков ” (пол. Łuk Mu akowa) - єдине кінцевоморенне п смо, яке видно з космосу. рім нього, геоп рк ми з г льнодерж вного зн чення $€$ “ ор вятої нни” т “ рконоський н ціон льний п рк” (див. т бл. 3).

Сьогодні н 3 верш льному ет пі є проекти геоп рків 3 г льнодерж вного зн чення: “ олин мєнней”, “ цвєж”, “ мяний ліс н озточчі”, “ лопольськ вріз н долин ісли”, “ ісляльодовиков кр їн р ви і ембніци”. е 14 (див. т бл. 3) перебув ють н ст дії пропозиції.

ериторії, які м ють сертифік т геоп рку з г льнодерж вного зн чення, н прох ння можуть включ ти в вропейську мережу геоп рків т в лоб льну мережу геоп рків, яку підтримує . окрем , 17 вересня 2011 р. польський геоп рк “ уг уж ков " отрим в сертифік т вропейського геоп рку [13].

ор 3 ч стіше ост ннім ч сом говорять про те, що геоп рк м, ст тус яких можн порівняти зі ст тусом об'єктів мережі Natura 2000, к тегорію яких впров джено в ольщі 2004 р., теж необхідно н д ти офіційну к тегорію природно-з повідного фонду ольщі.

кремі геомісця і геоп рки після відповідного рекл мув ння і н д ння доступу ст ють предмет ми туристичного з цік влення, тобто геотуристичними об'єКт ми. рештою, т кою є одн 3 цілей, з для яких ці об'єкти і створюють. оєдн ння геотуристичних тр кцій зі спеці льно створеними дид ктичними стежк ми д є змогу з цік вити туристів геологічною будовою конкретного р йону. цьому н прямі в ольщі ост нніми рок ми ведуть величезну роботу. прикл д цього - 3 г льнопольський к т лог геотуристичних об'єктів. 
еоп рки з г льнодерж вного зн чення, проекти яких уже зроблені бо розробляють

\begin{tabular}{|c|c|}
\hline обоч н зв геоп рку & жерело, де можн отрим ти інформ цію про проект \\
\hline мєнней” & http://voluminajurassica.org/pdf/volumen_II_1-16.pdf \\
\hline “ олин іслоки” & $\begin{array}{l}\text { http://www.turyzmdlaregionu.eu/gfx/turyzm/userfiles/_public/artykul } \\
\text { _2/majecka_wisniewska_artykul_kwartalny.pdf }\end{array}$ \\
\hline “ цвєж” & $\begin{array}{l}\text { http://www.pgi.gov.pl/index.php?option=com_content\&task=view\&i } \\
d=2172 \& \text { Itemid=608 }\end{array}$ \\
\hline рський” & http://www.zpk.com.pl/ochrona_przyrody/2007/program.doc \\
\hline “ м’яний ліс н озточчі” & http://kamiennylas.pl/ \\
\hline “ вгустовський к н л” & $\begin{array}{l}\text { http://www.turyzmdlaregionu.eu/gfx/turyzm/userfiles/_public/artykul } \\
\text { 22/majecka_wisniewska_artykul_kwartalny.pdf }\end{array}$ \\
\hline $\begin{array}{l}\text { “ лішові рп ти і їхні } \\
\text { мінер льні води” }\end{array}$ & $\begin{array}{l}\text { http://www.pgi.gov.pl/pl/wydawnictwa-geologiczne-pig- } \\
\text { pib/czasopisma/przeglad-geologiczny/3882-przegld-geologiczny- } \\
\text { 2011-09-tom-59 }\end{array}$ \\
\hline “ олян ш хт еличк” & $\begin{array}{l}\text { Alexandrowicz Z., Alexandrowicz S. Geoparks - the most valuable } \\
\text { landscape parks in Southern Poland // Polish Geological Institute. - } \\
\text { Special Papers 13. - 2004. - S. 49-56. }\end{array}$ \\
\hline $\begin{array}{l}\text { “ } \mathrm{p} \text { їн льодовикової епохи } \\
\text { н берег х дри” }\end{array}$ & http://www.moryn.pl/aktualnosci/dzial/146.dhtml \\
\hline $\begin{array}{l}\text { “лопольськ вріз н } \\
\text { долин ісли” }\end{array}$ & $\begin{array}{l}\text { http://www.pgi.gov.pl/pl/wydawnictwa-menu-tekst/link-menu-lewe- } \\
\text { wyd/przeglad-geologiczny/3694-przegld-geologiczny-2011-05-tom-59 }\end{array}$ \\
\hline “ нутрісудетський прогин” & $\begin{array}{l}\text { Alexandrowicz Z., Alexandrowicz S. Geoparks - the most valuable } \\
\text { landscape parks in Southern Poland // Polish Geological Institute. - } \\
\text { Special Papers } 13 .-2004 .- \text { S. 49-56. }\end{array}$ \\
\hline “ еніни” & http://oksir.nazwa.pl/Geopark/artykuly/pl/MISKIEWICZ.html \\
\hline $\begin{array}{l}\text { “ ісляльодовиков кр їн } \\
\text { р ви і ембніци” }\end{array}$ & http://www.partnerstwodrawy.org/epoka-polodowcowa,64,2.html \\
\hline “ онідщин ” & http://www.ujk.edu.pl/ios/konferencja.pdf \\
\hline “йон льбжих " & http://www.pgi.gov.pl/index.php?option=content\&task=view\&id=2317 \\
\hline “ ленж ” & $\begin{array}{l}\text { Alexandrowicz Z., Alexandrowicz S. Geoparks - the most valuable } \\
\text { landscape parks in southern Poland // Polish Geological Institute. - } \\
\text { Special Papers 13. - 2004. - S. 49-56. }\end{array}$ \\
\hline “ лодський сніжник” & $\begin{array}{l}\text { Alexandrowicz Z., Alexandrowicz S. Geoparks - the most valuable } \\
\text { landscape parks in Southern Poland // Polish Geological Institute. - } \\
\text { Special Papers 13. - 2004. - S. 49-56. }\end{array}$ \\
\hline $\begin{array}{ll}\text { “ } & \text { вєнтокшиський” } \\
\text { ( енцінсько- елецький) }\end{array}$ & http://www.geopark-kielce.pl/index.php?id1=74 \\
\hline
\end{tabular}

т лог геотуристичних об’єктів у ольщі (пол. katalog obiektów geoturystycznych $w$ Polsce) створений у ірничо-мет лургійній к демії в іністерств довкілля і профін нсов ний ціон льним фондом охорони довкілля т водного господ рств для популяриз ції геологічного минулого кр їни. ублік ція $є$ підсумком пр ці б г тьох геологів, геогр фів і осіб, професійно пов'яз них з охороною середовищ, з різних н укових уст нов. ерсія он-л йн 3 інтер ктивним пошуком об'єктів доступн н с йті іністерств довкілля [9].

етою роботи було виділення і з документув ння різних геотуристичних об'єктів, які $є$ в усіх воєводств х ольщі, н 6 зі з тверджених і з пропонов них для з твердження документ льних місць неживої природи. -поміж пон д 600 нових пропозицій докумен- 
т льних місць було вибр но 300 н йцік віших т н йцінніших з н уково-дид ктичного погляду. цього списку т зі списку р ніше з тверджених 138 документ льних місць вибр но групу 100 н йцік віших геотуристичних об'єктів. еотуристичні об'єкти були к т логов ні згідно з дміністр тивним поділом ольщі. ля отрим ння інформ ції про геотуристичні особливості того бо іншого об'єкт необхідно, передусім, вибр ти воєводство, потім - конкретний геотуристичний об'єкт. прикл д, н території юблінського воєводств до н йцік віших у м сшт бі всієї кр їни з числено п'ять об'єктів, с ме: “ рейдовий к р'єр у л жові”, “ тінк ож риських у к р'єрі в охотніци”, “ пнякові к р'єри в елебську і овін х”, “ есовий яр у онсядці”, “ к м'янілі пеньки в єдліск х”. ожен об'єкт дет льно опис ний польською й нглійською мов ми. пис охоплює: 1) лок ліз цію з ур хув нням: ) дміністр тивного, б) геологічного, в) геоморфологічного р йонув ння; 2) дет льну геологічну, геоморфологічну, п леогеогр фічну, стр тигр фічну х р ктеристику об'єкт ; 3) дет льну топок рту з з зн ченням об'єкт ; 4) фотогр фії.

тже, короткий перегляд структури ольщі з погляду охорони неживої природи д є змогу виділити як подібні риси зі структурою кр їни (н прикл д, існув ння к тегорії п м'яток неживої природи, охорону об'єктів неживої природи в меж х великопросторових форм), т к і відмінні (н прикл д, відсутність у системі кр їни к тегорії документ льних місць, як передб ч є охорону виняткових об'єктів, цінних з геологічного бо геоморфологічного поглядів; екологічних угідь, природно-л ндш фтних комплексів, у яких досить ч сто охороняють різні форми рельєфу), більшу роль у ольщі, особливо після 2009 р., орг нів с моврядув ння в створенні й зміні меж об'єктів г льноєвропейськ “мод” н геомісця і геоп рки, як охопил ольщу протягом ост нніх кількох років, т перспективи використ ння цих об'єктів неживої природи в геотуристичних цілях з свідчили необхідність внесення коректив у структуру ольщі для ліпшої експозиції об'єктів неживої природи і чіткішої їх к тегориз ції.

ьогодні н лічують 45636 об'єктів ольщі, що охоплюють пон д $32 \%$ території кр їн, 1888 дет льно прокл сифіков них геомісць, 3 геоп рки і 14 геоп рків н ст дії проекту. рив є величезн робот, спрямов н н створення дет льної б зи об'єктів , як з свідчує основне, чого можн і потрібно н вчитися в н ших сусідів, - б ж ння і вміння створюв ти й охороняти природоохоронні об'єкти i, зокрем , об'єкти неживої природи, небув лий ентузі зм і м сшт бність, з якою н всіх рівнях, почин ючи від лок льного гмінного і з кінчуючи з г льнодерж вним, ведуть роботи зі збереження для м йбутніх поколінь геологічної сп дщини, і бізнес-з п лу, з яким створюють геотуристичну мережу, як, крім фін нсових профітів для вл сників цих об'єктів, сприятиме популяриз ції геологічного минулого кр їни. 


\section{СПИСОК ВИКОРИСТАНОЇ ЛІТРАТУРИ}

1. о собою являє природно-з повідний фонд кр їни. м тері л ми н літичної довідки, н д ної бінетом іністрів, про ст н 3 повідного фонду в кр їні т перспективи його розвитку [ лектронний ресурс]. - Січень 2011. - [Cited 2012, 18.10]. - ежим доступу: http://ridna.ua/2011/01/uryad-propolyuvannya-ta-stanpryrodno-zapovidnoho-fondu/

2. Bochenek D. Ochrona środowiska 2011 / Informacje i opracowanie statystyczne GUS [ лектронний pecypc] - Październik 2011. - [Cited 2012, 10 wrzes.]. - ежим доступу: http://www.stat.gov.pl/cps/rde/xbcr/gus/se_ochrona_srodowiska_2011.pdf.

3. Centralny rejestr geostanowisk Polski [ лектронний pecypc]. - 31.07.2012 - [Cited 2012, 31 lipiec.]. - ежим доступу: http://www.crgp.pl/gsapp/

4. Centralny rejestr form ochrony przyrody w Polsce [ лектронний pecypc]. - zerwiec 2012. - [Cited 2012, 31 sierp.]. - ежим доступу: http://crfop.gdos.gov.pl/

5. Czubinski Z. Rezerwaty przyrody w Polsce / Z. Czubinski, J. Gawłowska, K. Zabierowski. - Stud. Nat. - 1977. - Ser. B. - 27 s.

6. Database of Polish Representative Geosites [ лектронний pecypc]. - 2006. - [Cited 2012, 10 wrzes.]. - ежим доступу: http://www.iop.krakow.pl/geosites

7. Geoparki i inne obiekty geoturystyczne w Polsce [ лектронний pecypc]. - Czerwiec 2012. - [Cited 2012, 10 wrzes.]. - ежим доступу: http://www.ekoportal.gov.pl/ opencms/opencms/ekoportal/warto_wiedziec_i_odwiedzic/Ekoturystyka/Geoparki/

8. Grabowski D. Klasyfikacja propozycji stanowisk dokumentacyjnych przyrody nieo ywionej przedstawianych na MGGP / D. Grabowski, M. Sikorska-Maykowska. Przegląd Geologiczny. - 2000. - Vol. 48. - N 9. - S. 821-824.

9. Katalog obiektów geoturystycznych w Polsce [ лектронний pecypc]. - Wrzesień 2012. - [Cited 2012, 10 wrzes.]. - ежим доступу: http://www.mos.gov.pl/kategoria/ 2398_katalog_obiektow_geoturystycznych_w_polsce/

10. Obszary chronionego krajobrazu w Polsce [ лектронний pecypc] - Lipiec 2012. [Cited 2012, 10 wrzes.]. - ежим доступу: http://www.ochrona-przyrody.edu.pl/ wiki/obszar-chronionego-krajobrazu

11. Parki krajobrazowe w Polsce [ лектронний ресурс]. - Sierpień 2012. - [Cited 2012, 8 wrzes.]. - ежим доступу: http://www.ochrona-przyrody.edu.pl/wiki/parkikrajobrazowe

12. Parki narodowe w Polsce [ лектронний pecypc]. - Sierpień 2012. - [Cited 2012, 10 wrzes.]. - ежим доступу: http://pl.wikipedia.org/wiki/Parki_narodowe_w_Polsce

13. Pierwszy certyfikat dla polskiego geoparku. Łuk Mu akowa - Europejskim Geoparkiem [ лектронний ресурс]. - Wrzesień 2011. - [Cited 2012, 10 wrzes.]. - ежим доступу: http://mos.gov.pl/artykul/7_16516.html

14. Ustawa z dnia 16 kwietnia 2004 r. o ochronie przyrody (Dz. U z 2004 r. Nr 92, poz. 880) [ лектронний ресурс]. - [Cited 2012, 10 wrzes.]. - ежим доступу: http://mos.gov.pl/ 


\title{
THE CHARACTERISTIC OF THE NATURE PROTECTION OF THE INANIMATE OBJECTS IN POLAND
}

\section{Inna Sirenko}

Ivan Franko National University of Lviv, Doroshenko St., 41, UA - 79000 Lviv, Ukraine

An attempt was made to present the state and the characteristic of the nature conservation in Poland. Mainly in that part which deals with inanimate nature objects; systematizing the experience of our neighbors by adapting existing organizational forms to the new forms introducted in the world, to show the most interesting of the existing classifications and principles of their creation.

Key words: forms of nature conservation, geoconservation, геор знообр зие, geodiversity, geotop, geoparks, geotourism.

\section{нн иренко}

\author{
ьвовский н ицон льный университет имени в н \\ ул. орошенко, 41, 79000, г. ввов, кр ин
}

ок 3 но состояние и специфику природно-з поведного фонд ольши, прежде всего в той ч сти, котор я к с ется охр ны объектов неживой природы. истем тизиров но опыт н ших соседей н пути приспособления существующих р нее природоохр нных к тегорий к новым, ктивно входящим в н шу жизнь в течение последнего десятилетия, приведено н иболее интересные кл ссифик ции и принципы, положенные в основу их созд ния.

лючевые слов : формы охр ны природы, геоохр н , геор знообр зие, геологическое н следие, геоместо, геоп рк, геотуризм. 